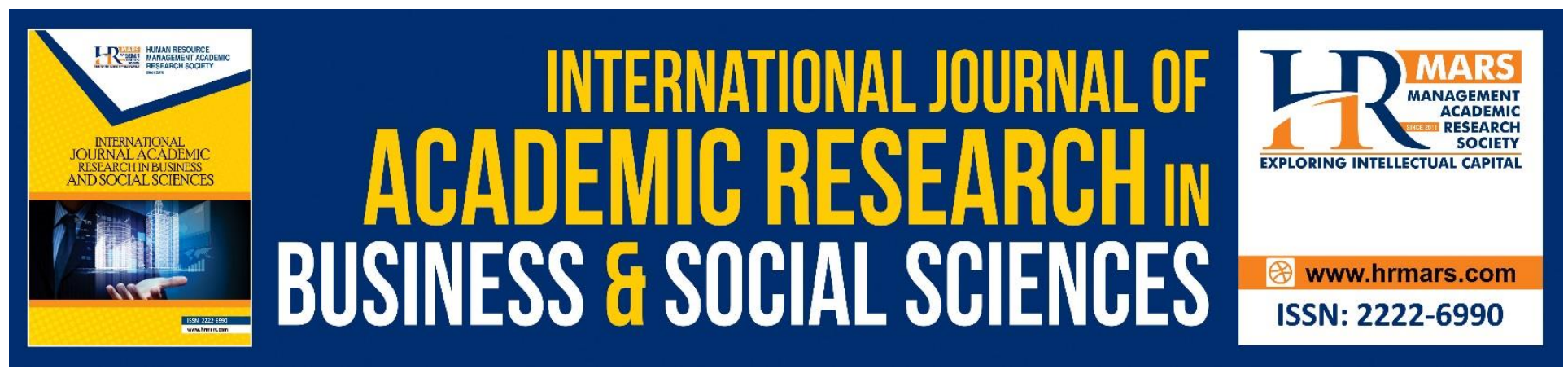

\title{
Microfinance and Women's Empowerment in Ghana: Challenges and Prospects
}

Owusu-Yeboah, Ebenezer, Owusu-Yeboah Gideon, Diane Uwineza

To Link this Article: http://dx.doi.org/10.6007/IJARBSS/v10-i10/7945

DOI:10.6007/IJARBSS/v10-i10/7945

Received: 08 August 2020, Revised: 28 August 2020, Accepted: 25 September 2020

Published Online: 20 October 2020

In-Text Citation: (Ebenezer, Gideon, \& Andrews, 2020)

To Cite this Article: Ebenezer, O-Y., Gideon, O-Y., \& Uwineza, D. (2020). Microfinance and Women's empowerment in Ghana: Challenges and Prospects. International Journal of Academic Research in Business and Social Sciences. 10(10), 377-404.

Copyright: (C) 2020 The Author(s)

Published by Human Resource Management Academic Research Society (www.hrmars.com)

This article is published under the Creative Commons Attribution (CC BY 4.0) license. Anyone may reproduce, distribute, translate and create derivative works of this article (for both commercial and non-commercial purposes), subject to full attribution to the original publication and authors. The full terms of this license may be seen

at: http://creativecommons.org/licences/by/4.0/legalcode

Vol. 10, No. 10, 2020, Pg. 377 - 404

http://hrmars.com/index.php/pages/detail/IJARBSS

JOURNAL HOMEPAGE

Full Terms \& Conditions of access and use can be found at http://hrmars.com/index.php/pages/detail/publication-ethics 


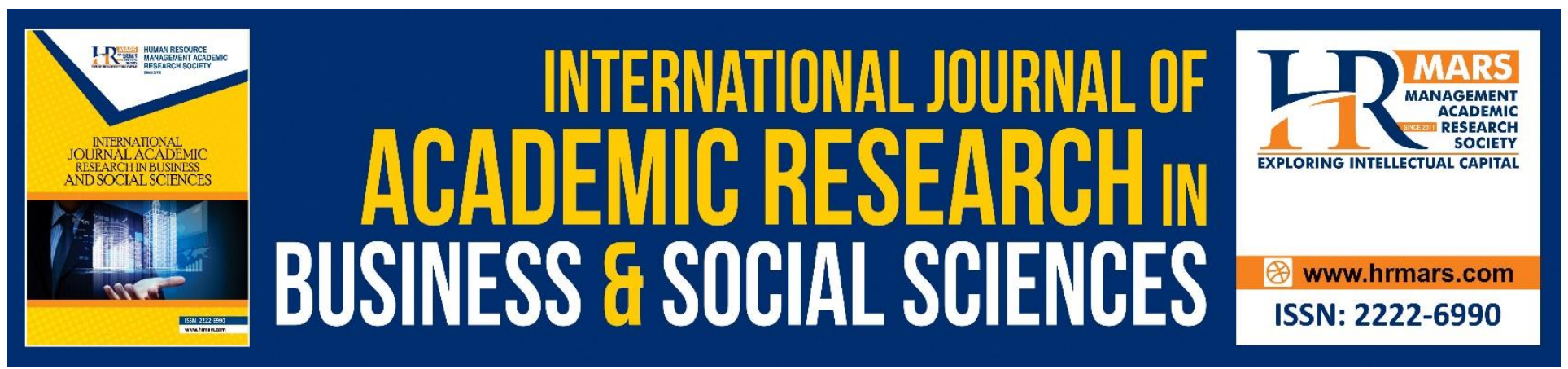

\title{
Microfinance and Women's Empowerment in Ghana: Challenges and Prospects
}

\author{
Owusu-Yeboah, Ebenezer \\ Adventist University of Philippines (PhD candidate) \\ Email: eowusu-yeboah@vvu.edu.gh \\ Owusu-Yeboah Gideon \\ University of Professional Studies Accra \\ Email: goy3217@gmail.com \\ Diane, Uwineza \\ Andrews University, USA. \\ Email: daniano022@yahoo.fr
}

\begin{abstract}
The study was to evaluate the contributions of microfinance institutions in Ghana to the empowerment of the Ghanaian women, taking a specific interest in the Challenges and prospects. Using a sample size of 210 respondents from three regions of Ghana, perspectives were sought from women who are beneficiaries of microfinance and the management of MFIs. It was observed that microfinancing is playing a key role in contributing to the individual lives of women by encouraging and providing the avenue for savings, providing loans and providing some level of business advice. The study also revealed that there is a bit of mission drift from the core object of the coming into being of MFIs to the extent that some MFIs target clients who can afford their loans at the interest rate charge backing it with the explanation of being able to sustain their business. The study revealed that this high-interest rate charged is pushing some women away from securing loans for their businesses. The study again revealed two main challenges facing the women to be: high-interest rate and the demand for guarantors and collateral for loans. The challenges facing the microfinance industry were: the decline of goodwill from the public, especially women client, lack of adequate regulatory framework and high default rate, which makes the cost of loans very expensive. Notwithstanding the challenges, the study observed that microfinance presents with greater prospects of empowering women economically through savings and loans only if the government will be up and doing to protect the industry from scammers with a strict supervisory and regulatory framework. The study recommends that the government and non-governmental organisations should support private MFIs to set up select units for only women which will lax interest rate and provide extensive business support for them.
\end{abstract}


INTERNATIONAL JOURNAL OF ACADEMIC RESEARCH IN BUSINESS AND SOCIAL SCIENCES Vol. 10, No. 10, 2020, E-ISSN: 2222-6990 @ 2020 HRMARS

Keywords: Microfinance, Microfinance Institutions, Contributions, Women Empowerment, Challenges and Prospects.

\section{Introduction}

Women contribute immensely to the well-being of the family, and their contributions to national development are duly recorded in history (Tegegne, 2012). Despite women's indisputable role in society and nation-building, it is on record that they face challenges of inequality and disempowerment (Benard, Jones, Oliker, Thurston, \& Lawson, 2008). Women have few opportunities to engage in economic activities, and the problem is more pronounced in the rural areas in Ghana. Against this backdrop, empowering women to take their rightful position in stature and nationbuilding has become a policy concern recently (Rwomire, 2011). The empowered woman is more confident, active in decision making and enhanced status, thereby encouraging gender equality (Rai, 2005).

Microfinance has, over the years, been identified as one of the channels to empower women economically. Indeed, empowering women to be economically viable through microfinancing projects has taken centre stage in development policy. Microfinance has helped women manage their roles as mothers, wives, and businesspersons. They help women to establish their businesses or expand existing ones. There continue to be many initiatives to provide microfinance schemes to rural folks, especially rural women (CEDAW, 2005). These initiatives have one common strategic conceptempowering women economically contributes to poverty alleviation and reduces the number of children living in poverty.

The concept of microfinancing gained prominence in Ghana during the 1980s when the state saw the need to provide support interventions and fill the gap left by banks in providing credit to individuals, micro, small and medium enterprises. This suggests that micro-financing has gained prominence in Ghana for over 36 years. However, issues concerning women economic empowerment, rural and urban poverty, and child poverty are still lingering around and needs to be rigorously addressed in Ghana. Indeed, microfinance critics have held strong dissenting views on the extent of influence microfinancing have on the livelihood of the individual to a large extent, and as such, the need for more rigorous analysis. In a study conducted by Banerjee, Duflo, Glennerster, and Kinnan in 2015, they noted that although microcredit succeeds in affecting household expenditure and creating and expanding businesses, it seems to have no apparent effect on education, health, or women's empowerment at least in the short term. They observed that "Microcredit, therefore, may not be the miracle that is sometimes claimed on its behalf, but it does allow households to borrow, invest, and create and expand businesses" (p.30). Norwood (2013) also concluded in his study that microcredit has no real impact on empowering the poor. Notwithstanding, many studies hold a contrary view to that of the critics, for instance, Bruno (2012) and other researches have observed that microfinance institutions have amassed hundreds of case studies showing that the loans are given to beneficiaries' help alleviate poverty, improve health, increase education and promote women's empowerment.

The position of this study, therefore, is to evaluate the contributions of microfinance institutions in Ghana to the empowerment of the Ghanaian women, taking a specific interest in the challenges and prospects of microfinance. 
INTERNATIONAL JOURNAL OF ACADEMIC RESEARCH IN BUSINESS AND SOCIAL SCIENCES

Vol. 10, No. 10, 2020, E-ISSN: 2222-6990 @ 2020 HRMARS

\section{Literature Review}

\section{The Concept of Microfinancing}

Microfinance, in a broader term, refers to a comprehensive set of financial services couture to fit the needs of poor individuals. Schreiner and Colombet (2001) define microfinance as "the attempt to improve access to small deposits and small loans for poor households neglected by traditional banks" (p.339). The concept and philosophy behind the formation of micro-financing institutions arose in the spirit of the need to provide for entrepreneurs who were left out by formal financial institutions (FFIs). Microfinance can be traced back to as far as 1462 when an Italian monk created the first official pawnshop in 1462 which was purposely set up to counter extortion practices at that time which was treading on a wrong path in his opinion (Graziani-Garcia, 2011). It has since then gone through various evolutions to the contemporary concept of microfinance. However, the fundamental philosophy has remained the same, thus to make credit available to the poor to enable them to use their agency out of poverty.

The concept gained prominence in Ghana during the 1980s when the state saw the need to provide support interventions. However, the concept and practice had not been new to Ghana since traditionally, people have saved and contracted small loans from individuals and groups within the context of self-help programme popularly known as 'SUSU' to start businesses or farming projects. It is noted that the first formal credit unions in Ghana were introduced in 1955 by a Catholic Priest Father Peter Poreku Dery in Jirapa in the Upper Region the present-day Upper West Region of Ghana (Egyir, 2010). He established it with the primary intent of helping the people out of poverty and providing them socio-economic support. It believed that the central government took inspiration from the great work of Father Peter Derry to introduce financial institutions such as National Investment Bank (NIB), Agricultural Development Bank (ADB), and Ghana Commercial Bank (GCB) to make credit available to the populace through these strategic avenues. Nevertheless, these banks were concentrated in the urban centres to the neglect of the poor in the rural areas hence the need to extend formal financial service to poor in rural communities gave birth to rural banks in the late 1970s.

It is worthy of notice that globally, the modern term of microfinance emanated from the microcredits which were given birth in the 1970s because of the persistent need to get people out of poverty through innovative ways that can help them fend for themselves through setting up of businesses. Leading forerunners of this idea included Grameen Bank in Bangladesh; ACCION International in Latin America, Self-Employed Women's Association (SEWA) in India. This new wave of methodology proved that poor people, especially women, are committed to loan payments hence more reliable (D'Espallier, Guerin, \& Mersland, 2009). It also brought to the fore that poor people, especially women, are willing and capable of paying interest rates on their loans. For instance, according to Professor Muhammad Yunus Grameen Bank in 2005, "it had nearly 6 million borrowers - 96\% of them women - and almost 2,000 branches in some 64,000 villages in Bangladesh. The repayment rate of loans stood at 95 per cent as of 2008, and the bank had earned a profit every year but three since its establishment 30 years ago" (Egyir, \& Akudugu, 2009, p.6).

This goes to prove the creditworthiness of women when it comes to borrowing. Many MFIs in Ghana have modelled on the Grameen concept and has proven successful (Egyir, \& Akudugu, 2009). The 1990s and beyond saw a commercial focus on the MFIs and the amendment of the NonBanking Financial Institution Act 2008 (Act 774), saw increasing involvement of the private sector in the MFIs (Duah, Neequaye, \& Kissedu, 2012). 
INTERNATIONAL JOURNAL OF ACADEMIC RESEARCH IN BUSINESS AND SOCIAL SCIENCES Vol. 10, No. 10, 2020, E-ISSN: 2222-6990 @ 2020 HRMARS

Again according to Egyir and Akudugu,(2009),

Microfinancing in Ghana was given its boost by the introduction of various financial sector policies and programs such as the provision of subsidized credits, establishment of rural and community banks (RCBs), the liberalization of the financial sector and the promulgation of PNDC Law 328 of 1991, that allowed the establishment of different types of non-bank financial institutions, including savings and loans companies, finance houses, and credit unions and so on has further strengthened microfinance activities in the country (p.6).

Three main types of microfinance are currently observed in Ghana. They comprise formal suppliers of microfinance; the semi-formal suppliers of microfinance; and the informal suppliers of microfinance. The formal suppliers comprise of the rural and community banks, savings, and loans companies, commercial banks. The semi-formal suppliers also comprise of credit unions, nongovernmental financial organisations (FNGOs), and cooperatives; and the informal suppliers comprise of 'susu' collectors and clubs, rotating and accumulating savings and credit associations (ROSCAs and ASCAs), traders, moneylenders and other individuals. MFIs in Ghana continues to grow, for instance, in October 2012, 161 MFls were recorded by the Bank of Ghana whilst this figure increased by 190\% to 468 as at November 2015 (Akotey, \& Adjasi, 2016, p.384). The sectors, as reported by PWC (2016), provide financial services to about $15 \%$ of the total population of Ghana and by this contributes significantly to the socio-economic wellbeing of the citizenry. Microfinance in Ghana just as all others emerged intending to fill the gap left by banks in providing credit to individuals, micro, small and medium enterprises.

\section{The Concept of Women's Empowerment}

Empowerment, and precisely women empowerment, have been explained by many authors and scholars. For instance, Kulkarni (2011) as cited in Zoynul, and Fahmida, (2013, p.5) observed that empowerment "is a process of change by which individuals or groups with little or no power gain the ability to make choices that affect their lives." Similarly, Krishna (2003) also contends that empowerment comes about when the capacity of individuals or groups are increased through the necessary means to the extent that, individuals or groups can make effective developmental and life choices and transform the choices to desired outcomes. For clarity, Malhotra et al. (2005), specially constructed a framework which suggests that women's empowerment occurs along the following dimensions; economic, socio-cultural, familial/interpersonal, legal, political, and psychological. On this breadth, Dejene, (2007) noted that women Empowerment refers to increasing and improving the social, economic, political and legal strength of the women, to ensure the equal right to women, and to make them confident enough to claim their fundamental rights.

In the light of this wisdom, organisations and people seeking to empower marginalised individuals especially women must embark on programs and policies that will promote the social, economic, political, and legal strength of the women and at the same time thwart attempts to deny marginalised individuals from these opportunities.

\section{Pioneer Workers in this Field}

Many individuals have contributed immensely to the work of micro-financing and empowerment of women. They include but not exhaustively, Friedrich Wilhelm Spooner, Muhammad Yunus, and Esther Afua Ocloo. Following are brief accounts of these individuals. 
INTERNATIONAL JOURNAL OF ACADEMIC RESEARCH IN BUSINESS AND SOCIAL SCIENCES Vol. 10, No. 10, 2020, E-ISSN: 2222-6990 @ 2020 HRMARS

\section{Friedrich Wilhelm Spooner}

According to Van Opstal, (2010), Friedrich Wilhelm Raiffeisen was born on 30 March 1818 at Hamm. It is submitted that Raiffeisen as a young mayor he established self help cooperative groups as a way of alleviaiting the suffering of farmers who were at the mercy of loan sharks. He had a philosophy that there is a connection between poverty and dependency. To fight poverty, one should fight dependency first. Based on this idea he came up with the three ' $S$ ' formula: self-help, selfgovernance, and self-responsibility. The noble concept founded the first cooperative lending bank, Rhenish Agricultural Cooperative Bank in 1872 at Neuwied with sole aim of putting into practice, the necessary independence from charity, politics and loan sharks.

\section{Muhammad Yunus}

Muhammad Yunus an economist and a banker who hails from Bangladeshi founded the Grameen Bank in India in 1983 after piloting microlending from 1976. As a professor of economics, Yunus studied the prevailing principles of finance and credit in his country which prevented the poor entrepreneurs from qualifying for bank loans, thus robbing them of the chance to overcome their poverty. He started by giving personal loans of very small or "micro" amounts to destitute basket weavers so that they could support themselves.

The purpose of setting up the bank was to make available small loans to the poor at reasonable rates to encourage self-employment opportunities that would help the poor by utilising their skills and making economic gains. Hashemi (1997) estimated about $97 \%$ of the borrowers from Grameen Bank to be women.

The establishment of the Grameen Bank in 1983 was the manifestation of his desire to help poor people. Evidence has it that several other banks modelled on the Grameen Bank business model operate in over 100 countries (Yunus, 1999). Yunus had always been interested in social issues. He became interested in poverty reduction methods after famine struck Bangladesh in 1974 . He is a member of the board of the United Nations Foundation and has won numerous awards for his endeavours.

\section{Esther Afua Ocloo}

Esther Afua Ocloo born Esther Afua Nkulenu was a Ghanaian entrepreneur and pioneer of microlending in Ghana. She was one of the founders of Women's World Banking in 1976, with Michaela Walsh and Ela Bhatt and served as its first chair of trustees. She was born on April 18, 1919, and died on February 8, 2002. She was the first black person to obtain a cooking diploma from the Good Housekeeping Institute in London and was the first President of the Federation of Ghana Industries from 1959 to 1961 . She was extensively involved at a national and international level in the economic empowerment of women. As an advisor to the first World Conference on Women in Mexico in 1975, she promoted the availability of credit to women as a founding member and the first chairman of the Board of Directors of Women World Banking from 1979 to 1985 (Martin, 2002).

\section{Leading Institutes and Other Places of Influence}

Many institutions and organisations have had a tremendous influence on the development of Ghana, Africa, and other developing nations through various development vehicles, including microfinancing and empowerment of the underprivileged, especially women. Some of these institutions 
INTERNATIONAL JOURNAL OF ACADEMIC RESEARCH IN BUSINESS AND SOCIAL SCIENCES Vol. 10, No. 10, 2020, E-ISSN: 2222-6990 @ 2020 HRMARS

include but not exhaustively the World Bank, the United Nations Development Programme, and Grameen Bank. The following paragraphs take a brief look at these institutions.

\section{The World Bank}

The World Bank, established in 1944, is a corporation made up of 189 member countries with its headquartered in Washington, D.C. According to Cruz, Foster, Quillin, and Schellekens, (2015), the World Bank has two main goals for the world to achieve by 2030: (a) to end extreme poverty by decreasing the percentage of people living on less than $\$ 1.90$ a day to no more than $3 \%$ and (b) to promote shared prosperity by fostering the income growth of the bottom $40 \%$ for every country.

The World Bank is a vital source of financial and technical assistance to developing countries around the world. They provide low-interest loans, zero to low-interest credits, and grants to developing countries. The World Bank has directly reached out to the poor in Ghana, especially women, through social intervention concepts such as social investment funds (SIF). On the microfinance front, the SIF as at 2008 has recapitalized a total of 32 microfinance institutions mainly rural banks to the tune of 3million US dollars to provide micro-credit to over 14000 micro-enterprises out of which $80 \%$ were owned by women (Reviewing-microfinance-companies, 2008).

\section{United Nations Development Programme (UNDP)}

The United Nations Development Programme (UNDP) is the United Nations' global development network with its Headquartered in New York City. The UNDP partners globally with all levels of society in about 177 countries and territories and advocates for change and connects countries to knowledge, experience, and resources to help people build a better life. The UNDP focuses on poverty reduction, HIV/AIDS, democratic governance, energy and environment, social development, and crisis prevention and recovery. UNDP also encourages the protection of human rights and the empowerment of women in all its programs. Their main goal in Ghana is to help Ghana to achieve sustainable development goals and improve the lives of the poorest women and men, the marginalised and the disadvantaged in the country.

The UNDP has embarked on uncountable developmental programmes to help improve the lives of women and the underprivileged to help reduce poverty. To cite but just two, the UNDP and Japan teamed up to strengthen female entrepreneurs in Ghana by increasing production of the shea butter. The project facilitated the creation of synergies among various shea butter production groups in the northern region of Ghana (Esinam, 2010).

Again, The UNDP under the Microstar Programme provided a grant capital to 10 microfinance institutions over three years between 2007 and 2010, to build their capacity and overcome challenges faced with the lack of knowledge in the rudiments of pro-poor lending. This was done with the sole aim of empowering the MFIs to fight against abject poverty and hunger.

\section{Grameen Bank}

The Grameen Bank was founded by Professor Mohammad Yunus, a Fulbright scholar in the United States from Bangladesh in October 1983. The bank was founded on the belief that people have limitless potential, and releasing their resourcefulness and creativity helps them to end poverty. It had the main objective to promote financial independence among the poor, and it mainly targets the poorest of the poor, with an emphasis on women, who receive 95 per cent of the bank's loans (History of Grameen Bank, 2016). 
INTERNATIONAL JOURNAL OF ACADEMIC RESEARCH IN BUSINESS AND SOCIAL SCIENCES Vol. 10 , No. 10, 2020, E-ISSN: 2222-6990 @ 2020 HRMARS

\section{Professional Networks}

There are professional networks who have dedicated their entire mission to the development of the undeveloped world like Ghana and the empowerment of the underprivileged in societies, especially women. Some of these professional bodies include but not exhaustively, African Women's Development Fund (AWDF), Microfinance and Small Loans Center (MASLOC), Community Based Rural Development Programme and Social Investment Fund Project. The proceeding paragraphs take a brief look at one of these professional networks.

\section{Microfinance and Small Loans Centre}

Microfinance and Small Loans Centre (MASLOC) was set up in 2006 by the government of Ghana to serve as the critical fiduciary agency of the government for the prudent and judicious management of government's micro and small-scale credit programme targeted at reducing poverty, creating jobs and wealth.

It is particularly mandated to carry the following specific functions:

1. Hold in trust Government of Ghana and Development Partners' funds to administer micro and small-scale credit programmes.

2. Provide, manage, and regulate approved funds for microfinance and small-scale credit, loan schemes, and programmes.

3. Be a microfinance apex body responsible for:

a). The coordination and facilitation of the activities of institutions and organisations in the microfinance subsector of the economy

b). Promoting and enhancing the development of a decentralised micro financial system

c). The Co-operation, collaboration, and complementarities with other non-bank financial institutions in the operations of microfinance services.

The centre provides financial support to pro-poor programmes such as the Ministry of Fisheries and the Ministry of Women and Children Affairs. Disbursements support schemes such as women in entrepreneurship, micro-credit enterprise, and youth credit schemes, Guinea fowl rearing, agro-processing, women in poultry and much more (Perpetual, 2012).

\section{Pertinent Policy Issues}

Microfinance and women's empowerment have some pertinent guiding principles to help each achieve its intended outcome. Microfinance and women's empowerment in its entirety is policy tools for poverty alleviation. Microfinance policies in Ghana have the intended objective to promote the delivery of efficient and sustainable microfinance services to achieve wealth creation and poverty reduction. The intended outcome of the establishment of microfinance is to champion poverty alleviation; therefore, the following pertinent policy issues raise concern: poverty alleviation; capital requirement; area of coverage; the role of the government; consumer protection; capacity building; regulation and supervision; promotion of best practices; and performance standards. Each of these issues details principles that guide MFIs to ultimately use micro-finance as a tool for poverty alleviation and empowerment.

Women's empowerment policies, on the other hand, have the intended outcome to help women to have a positive influence on development by increasing their capabilities through indirect indicators like education and work participation of women, and direct indicators of female empowerment such as decision-making, mobility and access to economic resources that can be 
INTERNATIONAL JOURNAL OF ACADEMIC RESEARCH IN BUSINESS AND SOCIAL SCIENCES Vol. 10, No. 10, 2020, E-ISSN: 2222-6990 @ 2020 HRMARS

viewed both as an outcome and a process (Roy \& Niranjan, 2004). Some pertinent policy issues observed in this regard include capacity building; poverty reduction; economic empowerment \& livelihoods development; gender and education; gender and health and HIV/AIDS; gender human rights; gender and the environment.

\section{Pertinent Ethical or Philosophical Issues}

Microfinance institutions have come under a mountain of criticism springing from the fact that MFIs are unethically making high profits from the sweat of the poor in the name of poverty alleviation (Boateng, 2014). Some of these issues centre around interest rates and methods of loan recovery.

\section{Interest Rates and Forceful Loan Recovery Practices}

However, the pro MFIs have argued that due to high transactional cost and risk involve in the disbursement of loans to clients, MFIs are justified to charge such interest rates if they are to stay in business. It is also argued that microfinance has beneficial effects on the poor despite comparatively high-interest rates.

Ethical concerns have been raised regarding the coercive loan recovery strategies used by some MFIs. This always positions the MFIs in the wrong angle of the public opinion. It also raised concerns about the effectiveness of policy strategies that sees to the disbursement and monitoring and motivation of clients to repay. It has been argued out that, coercive recovery strategies employed by some MFIs is probably not the best of strategies if MFIs are to live to fulfil the motivating philosophical underpinning of its formation.

\section{Impact of microfinance on women empowerment in the world}

Many studies have empirically concluded that microfinancing projects have yielded positive results in empowering women all around the world (Buvinic, \& Furst-Nichols, 2016). This is not different in Ghana, riding on the back of such successes, the UNDP has funded many microfinance interventions. Most of these projects have targeted women in the rural environment, especially in the northern region of Ghana. Evidence from these projects has shown that microfinance projects have significantly improved the economic standing of the poor as well as increasing women's security, autonomy, self-confidence, and status within households (Khan, \& Noreen, 2012). One of such projects has been run by HAF's. HAF's microfinance project aims to provide local individuals, groups, and communities with the proper skills training and micro-loans to grow their business, create jobs, and promote empowerment.

However, in a 2005 study on the effects of microcredit in Ghana, Norwood found that microcredit has no real impact on empowering the poor. Similarly, Sobhan (2005) is of the view that sponsoring microcredits programmes for the poor to survive in the informal sector will not necessarily eradicate poverty, but he instead suggests a holistic approach to solving the poverty problem. Notwithstanding the views of Sobhan and Norwood, many policies on poverty eradication and empowerment recommend microfinancing as a sure way out of poverty (Addae-Korankye, 2012). This is probably because, about $91 \%$ of Ghanaian women are self-employed, and it is generally observed that women have greater difficulty in raising start-up for business than men (Carter \& Cannon, 1992). This evidence goes to show that, when microfinancing programmes are active, it will 
INTERNATIONAL JOURNAL OF ACADEMIC RESEARCH IN BUSINESS AND SOCIAL SCIENCES Vol. 10, No. 10, 2020, E-ISSN: 2222-6990 @ 2020 HRMARS

go a very long way to help empower more women financially. Therefore, it is prudent for the area to receive enough research attention to be effective.

\section{Challenges and Prospects of Microfinancing}

First, microfinance faces a significant challenge of survival and fulfilling its underlying philosophy of helping the poor due to the issue of interest rates. Due to the high risk of default probabilities and transactional cost, MFls charge higher interest rates compared to commercial banks. This makes microfinance products and service too expensive, which deter most of the intended indigent clients from accessing the services.

Secondly, According to Pollinger, Outhwaite, and Cordero-Guzmán, (2007), another major challenge of MFI's is the difficulty of accessing capital from Non-Governmental Organisations (NGO's) and mainstream financial institutions due to their high-risk client portfolio. Most find it difficult to satisfy the Bank of Ghana requirements of collateral, documentary evidence and long-standing bankcustomer relationship. It is against this backdrop that many MFI's tend to rely heavily on their lending rates and related operational activities in their bid to become financially sustainable (Dzisi, \& Obeng, 2013).

Also, it is noted that the microfinance business environment is faced with an unfavourable legal environment where there exists a lack of loan contract enforcement; therefore, aiding high default rate (Addae-Koranky, 2012). The sector is also fraught with the shortage of experienced human resources and Shortage of Logistics in rural areas such as road, telephone, etc. which impedes the effective administrative functions of MFIs (Osei, 2007).

Another major challenge is the lack of adequate information about the client's financial management and the absence of recorded evidence. This makes the MFIs to rely on fellow group member's oral information which possesses screening challenge (Asiamah \& Osei, 2007). Furthermore, the ability of clients to invest in profitable business ventures to generate profit to aid loan payment has posed a challenge.

Despite the challenges, microfinance in Ghana grins with prospects springing from the remarkable strides it has made in the country so far. Through microfinancing projects, the government of Ghana and other development partners have been able to finance many small-scale enterprises and self-help groups. For instance, the Ghana Business News in their publication in December 2014 noted that as at December 2014 MASLOC had disbursed over GHC153 million, arising out of injection of new funds and ploughing back of the recovered loan, covering 274,277 beneficiaries including 185,717 for females which translate into 67.7 and 88,560 for males (Ghana Business News, 2014).

Aside from the provision of funds, MFIs provides capacities building programmes for clients in areas of loan management, customer care, and marketing, among others. Microfinance as a tool for poverty alleviation and women's empowerment shines with many prospects based on what they have done and continues to do and the unflinching support they receive from the Government of Ghana and other development partners like the UNDP, and the World Bank.

\section{Best Practices}

Best practices in every field vary and changes with time as the specific industry matures (Palmer, \& Dunford, 2008).). Microfinancing and women's empowerment field is not exempted. Best 
practices can be termed as the practices that the field follows in providing services that will lead to the achievement of stated objectives. It must be reflected in all stages of implementation.

Best practices must reflect the philosophy and objectives of MFI as a vehicle for poverty alleviation and women's empowerment right through to implementation. In microfinancing, it is the best practice for MFIs to provide high quality and friendly services and environment for clients to feel welcome and not intimidated. Client selection must also be based on a rigorous assessment of character and repayment capacity but not on collateral. Loans must also be disbursed to identified clients or women group and monitored properly. Again, MFls must make account officers responsible for loans they have recommended for approval and maintain regular contact with clients and institute delinquency alarm signals to reduce default rate. Moreover, to encourage clients to repay, MFIs must encourage joint liability, reward clients who pay on time and impose penalty charges for late payment.

\section{Methodology \\ Introduction}

This chapter explains how the study was conducted. It gives details of the type of research design used, selection, and description of the site and the participants, ethical considerations, data collection strategies and data analysis strategies.

\section{Research Design}

Saunders, Lewis, and Thornhill (2012) viewed research design as a "Framework for the collection and analysis of data to answer the research question and meet research objectives providing a reasoned justification for the choice of data source, collection, and analysis techniques" (p.680). Based on the researcher's pragmatic philosophical standpoint, she is of the view that to understand the impact of microfinance on women's empowerment and copiously appreciate the challenges and prospect warrants a research design deep-seated in both qualitative and quantitative epistemology. This design gives the researcher the latitude to obtain the subjective and objective view of the respondents.

Mixed method design is defined by Kemper, Springfield, and Teddlie (2003) as a method that uses both qualitative and quantitative data collection and analysis in parallel form. Creswell (2013), also describes the mixed-method design as:

One in which the researcher tends to base knowledge claims on pragmatic grounds (e.g., consequence-oriented, problem-centred, and pluralistic). It employs strategies of inquiry that involve collecting data either simultaneously or sequentially to understand research problems (p.18) best.

Creswell (2009) argued that researchers employ a mixed-method design to broaden understanding by incorporating both qualitative and quantitative research or to use one approach to understand better, explain, or build on the results from the other approach. The advantages of using this method of inquiry are widespread in the literature (Johnson \& Onwuegbuzi, 2004; Sale, Lohfeld \& Brazil, 2002). Consequently, the study adopts a mixed-method research design to address the research questions.

\section{Selection and Description of the Site and the Participants}

Population, according to Singh and Bajpai (2007), is "the entire mass of observations, which is the parent group from which a sample is to be formed" (p. 40). They further defined Sampling as 
INTERNATIONAL JOURNAL OF ACADEMIC RESEARCH IN BUSINESS AND SOCIAL SCIENCES Vol. 10, No. 10, 2020, E-ISSN: 2222-6990 @ 2020 HRMARS

"selecting a given number of subjects from a defined population as representative of that population" (p.41). Mouton (1996) defines a sample as elements selected to find out something about the total population from which they are taken. Sampling technique is the method used in selecting a subset of individuals from within the defined population (Barreiro \& Albandoz 2001).

The population of the study was all registered microfinance institution in Ghana and their women beneficiaries in Ghana. Various forms of sampling techniques were used to select participants. Thirty (30) MFIs from three regions-Greater Accra, Ashanti and Brong-Ahafo, were selected for the study using a purposive sampling technique. This method was used because only MFIs who agreed to take part in the study were selected. Two (2) members of management position were interviewed for detailed responses, and then sixty (150) women clients from the MFIs were sampled using a snowball sampling technique to respond to a questionnaire. This method was used because it was the most effective method to reach the women beneficiaries within the short space of time. In all 210 respondents were sampled for the study (see Table 1).

Table 1: Sample Size

\begin{tabular}{|l|l|l|l|}
\hline & Expected sample size & \multicolumn{2}{|l}{} \\
\hline Regions & 3 & Expected number of participants \\
\hline MFIs & 30 & MFIs Managers & 60 \\
\hline Women Beneficiaries & 150 & Women Beneficiaries & 150 \\
& \multicolumn{2}{|l|}{ Total } & 210 \\
\cline { 2 - 3 } & &
\end{tabular}

\section{Ethical Consideration}

In the collection of data, the researcher needs to take into consideration the feelings, welfare, and rights of the participants and protect the same. First, the researcher wrote to selected MFIs to obtained authorization to conduct the research explaining the aim and purpose of the research and also ensuring the confidentiality of data and anonymity. Secondly, consent was sought from the members of the management team for the short interview. Participation was entirely voluntary, and the purpose and aim of the research were explained to them, and they were also assured of confidentiality and anonymity.

Finally, the purpose and aim of the research were gain explained to the women beneficiaries who were reached in languages they understood which were mainly English and Twi. Again, participation was wholly voluntary, and they were assured of anonymity and confidentiality.

\section{Data Collection Strategies}

The research was guided by a mixed methodological approach; hence both qualitative and quantitative data was collected. Arrangements were made on when, how and where interviews of the MFI managers could be done. Appointments were arranged with them at various times, and short interviews were conducted with them by the researcher.

Through referrals, women beneficiary of microfinancing were identified, and consent was sort for participation in the study. Assistance was sought from research assistance in Ashanti and Brong Ahafo region to deliver and collect research questionnaire. The concept, purpose and aim of the research and the research questionnaire was explained to them to aid them to explain the questionnaire when necessary and assist in the completion of the questions when there was the need for translation and assistance. The research assistants were asked to ensure confidentiality, and 
INTERNATIONAL JOURNAL OF ACADEMIC RESEARCH IN BUSINESS AND SOCIAL SCIENCES Vol. 10, No. 10, 2020, E-ISSN: 2222-6990 @ 2020 HRMARS

assure respondents of anonymity and that their names were not necessary. The researcher, however, took care of the women beneficiary respondents in Greater Accra and followed the procedure, but due to language barrier of the local dialect, the researcher employed the services of translators in some occasions. There was no need for translators in the interviews because all the managers interviewed could speak and understand the English language.

\section{Data Analysis Strategies}

Quantitative data from the questionnaire was sorted and edited to ensure logical completeness and consistency of response. Then the data were analysed using Statistical Package for Social Science (SPSS) version 20.0. Specifically, descriptive statistics were utilised harnessing on descriptive graphs and tables to describe the responses.

The interviews were transcribed, categorised, and cross-checked. Using coding methods, themes, and patterns to draw conclusions and recommendation.

\section{Findings}

\section{Data Presentations and Description of Quantitative Findings}

To address the research questions to ascertain the impact of MFIs on empowerment of women, questionnaires were sent out to women clients of microfinancing to assess their day to day interactions with MFIs and their views on the extent they feel microfinancing has impacted on their lives. 28 questions were asked to ascertain; (i) The profile of respondents (ii) type of services provided by the MFIs aside cash credit (iii) the impact of micro financing on the living condition of respondents (iv) the quality of service provided by the MFIs and ( $v$ ) the challenges associated with attainment and payment of credit.

One hundred and fifty (150) questionnaires were sent out to women clients of MFIs. One hundred forty-two valid responses were received, representing $94.6 \%$ response rate. Sixty managers were scheduled for interviews, but 37 of them could grant interviews which represent $61.7 \%$ response rate. In all, 210 respondents were expected, but 179 valid responses were received, which represents $85.2 \%$ response rate. 
INTERNATIONAL JOURNAL OF ACADEMIC RESEARCH IN BUSINESS AND SOCIAL SCIENCES Vol. 10, No. 10, 2020, E-ISSN: 2222-6990 @ 2020 HRMARS

\subsubsection{Profile of Respondents}

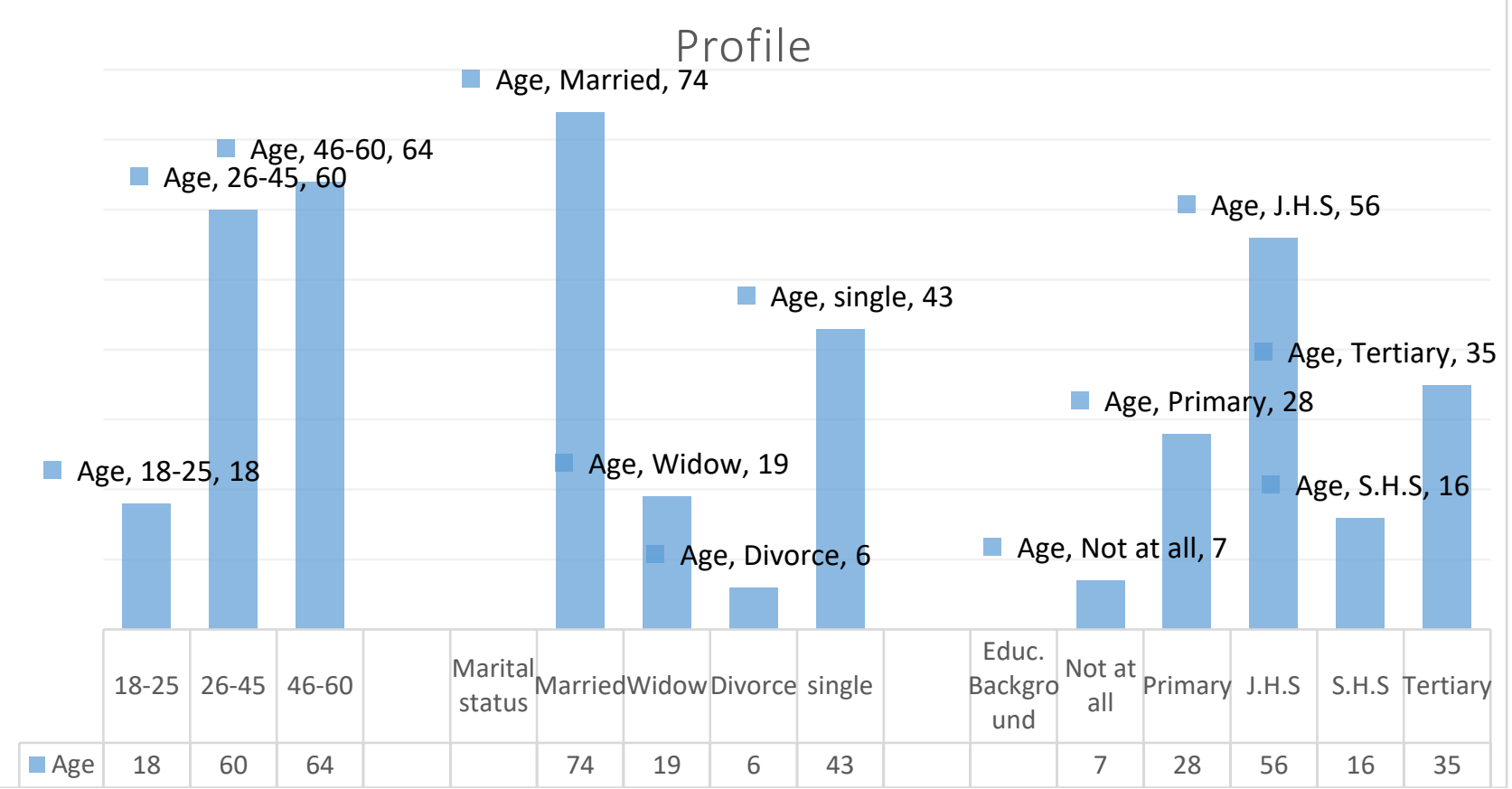

Figure 1: Profile of Women Clients who responded to the questionnaire

Source: Field Data, 2017

Figure 1 shows the profile of women beneficiaries of MFIs from the three regions-Ashanti, Brong-Ahafo and Greater Accra who took part in the study. It is observed that majority of the respondents were aged between 46-60 majority were also married, and the majority had at least JHS level of education. Many of them were also aged between 26-45; thus, 60 out of the 142, representing $42.3 \%$. What was striking is that, a considerable number of the respondents had tertiary education, thus 35 out of 142 , representing $24.6 \%$. 


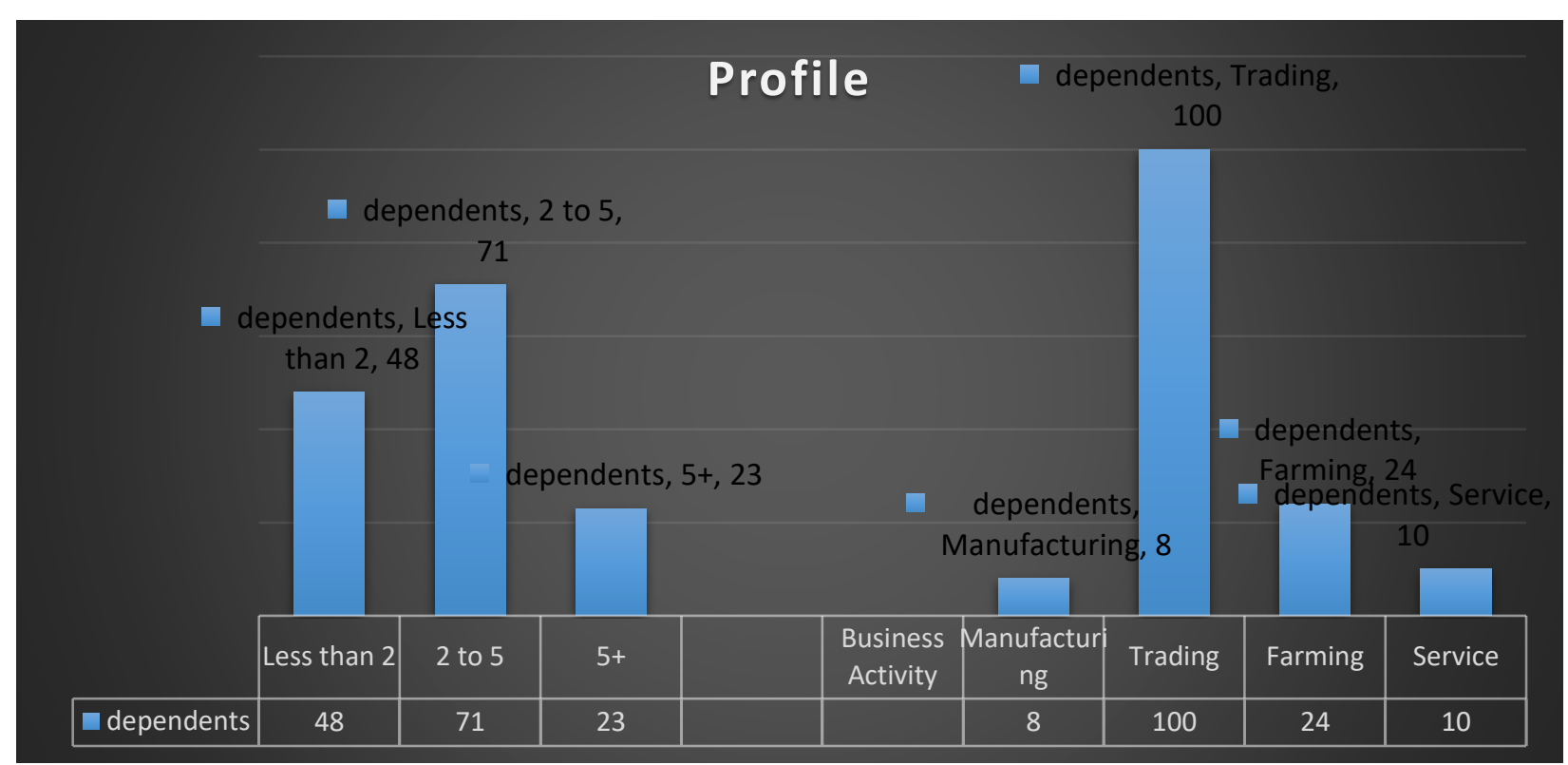

Figure 2: Profile of Women Clients who responded to the questionnaire

Source: Field Data, 2017

Figure 2 depicts the number of dependents and the business activities of the women clients of MFIs who took part in the study. From the graph, it is observed that most of the respondents had dependents between two to five and a few had dependents more than five. Most of them too engage in trading and few were engaged in manufacturing. $70.4 \%$ of the respondents were engaged in trading as against $5.6 \%$ who were engaged in manufacturing.

Type of Services Provided by MFIs aside Cash Credit

Table 2: Services provided by MFIs

\begin{tabular}{|c|c|c|c|c|c|}
\hline \multicolumn{6}{|c|}{$\begin{array}{l}\text { Apart from financial assistance, wh } \\
\text { microfinance/institution }\end{array}$} \\
\hline & & Frequency & Per cent & Valid Percent & $\begin{array}{l}\text { Cumulative } \\
\text { Percent }\end{array}$ \\
\hline \multirow{5}{*}{ Valid } & $\begin{array}{l}\text { gave advice on how to } \\
\text { sustain business }\end{array}$ & 36 & 25.4 & 25.4 & 25.4 \\
\hline & No assistance & 36 & 25.4 & 25.4 & 50.7 \\
\hline & $\begin{array}{l}\text { advice on alternative } \\
\text { business ventures }\end{array}$ & 35 & 24.6 & 24.6 & 75.4 \\
\hline & advice on savings & 35 & 24.6 & 24.6 & 100.0 \\
\hline & Total & 142 & 100.0 & 100.0 & \\
\hline
\end{tabular}

Source: Field Data, 2017

Table 2 above shows the service provided by MFIs apart from cash credits. Indeed $25.4 \%$ of the respondents indicated that their MFIs did not assist at all to them apart from cash credits. However, it is observed that $74.6 \%$ of the respondents indicated that the banks offered them other forms of services which includes advice on how to sustain their business, advice on alternative business ventures and advice on savings culture. 
INTERNATIONAL JOURNAL OF ACADEMIC RESEARCH IN BUSINESS AND SOCIAL SCIENCES Vol. 10, No. 10, 2020, E-ISSN: 2222-6990 @ 2020 HRMARS

\section{Impact of Microfinancing on Living Conditions of Beneficiaries (women)}

The impact of microfinancing on the living conditions of women was assessed through the following indicators; the number of years they have been with the MFls, the most frequent transaction they do with the MFIs, the frequency of loans accessed from the MFIs, the purpose for which they access to credit, their perception of the impact of credit accessed on their personal lives, and their perception on MFI loans as a poverty alleviation tool. The proceeding graphs gives details of the findings.

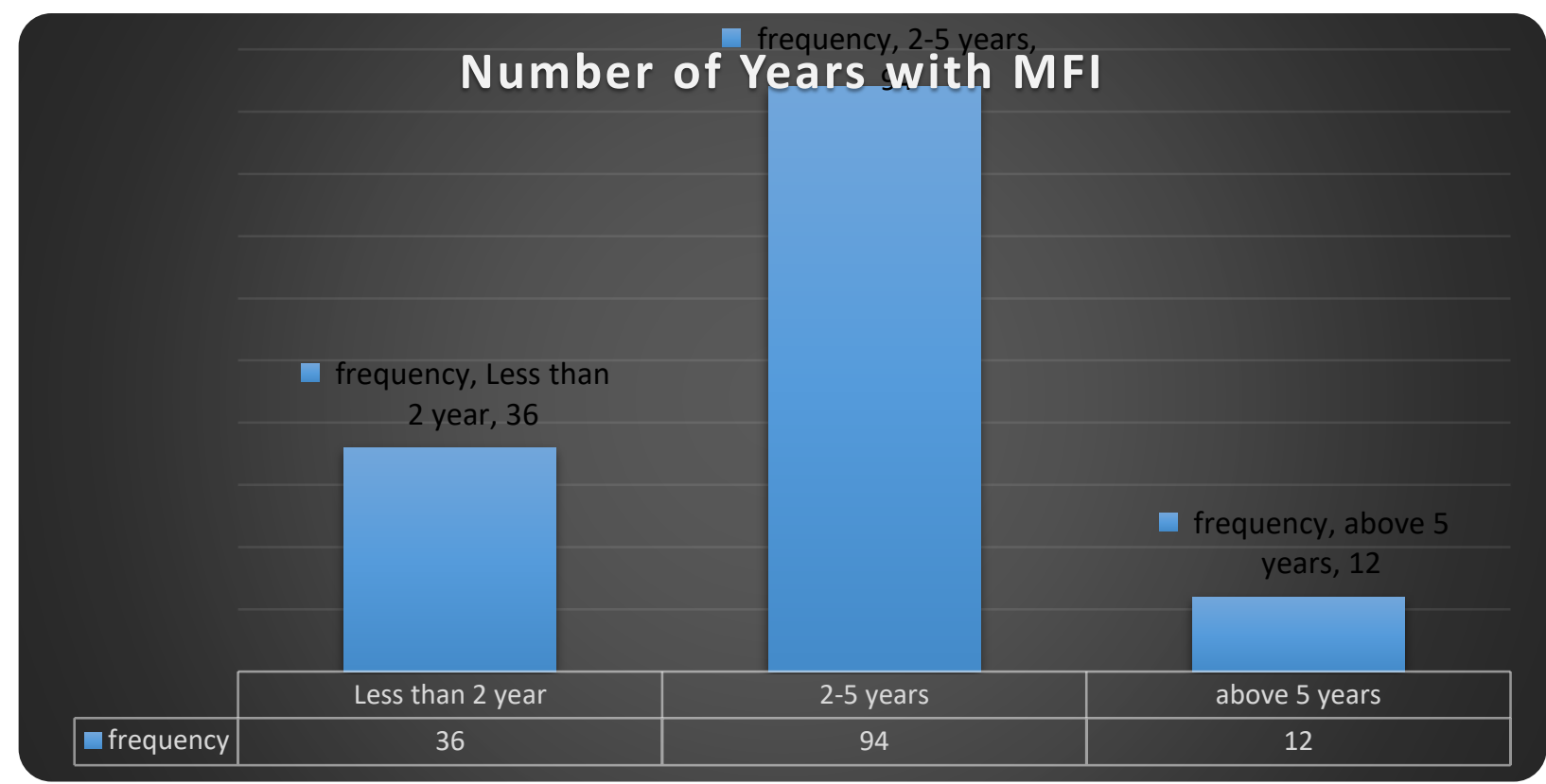

Figure 3: Number of Years with the MFI

Source: Field Data, 2017

Figure 3 displays the number of years of the respondents had been with the MFIs. It is observed that the majority of them has been with their MFIs for 2 to 5 years while very few of them has been with their MFIs for more than 5 years. 


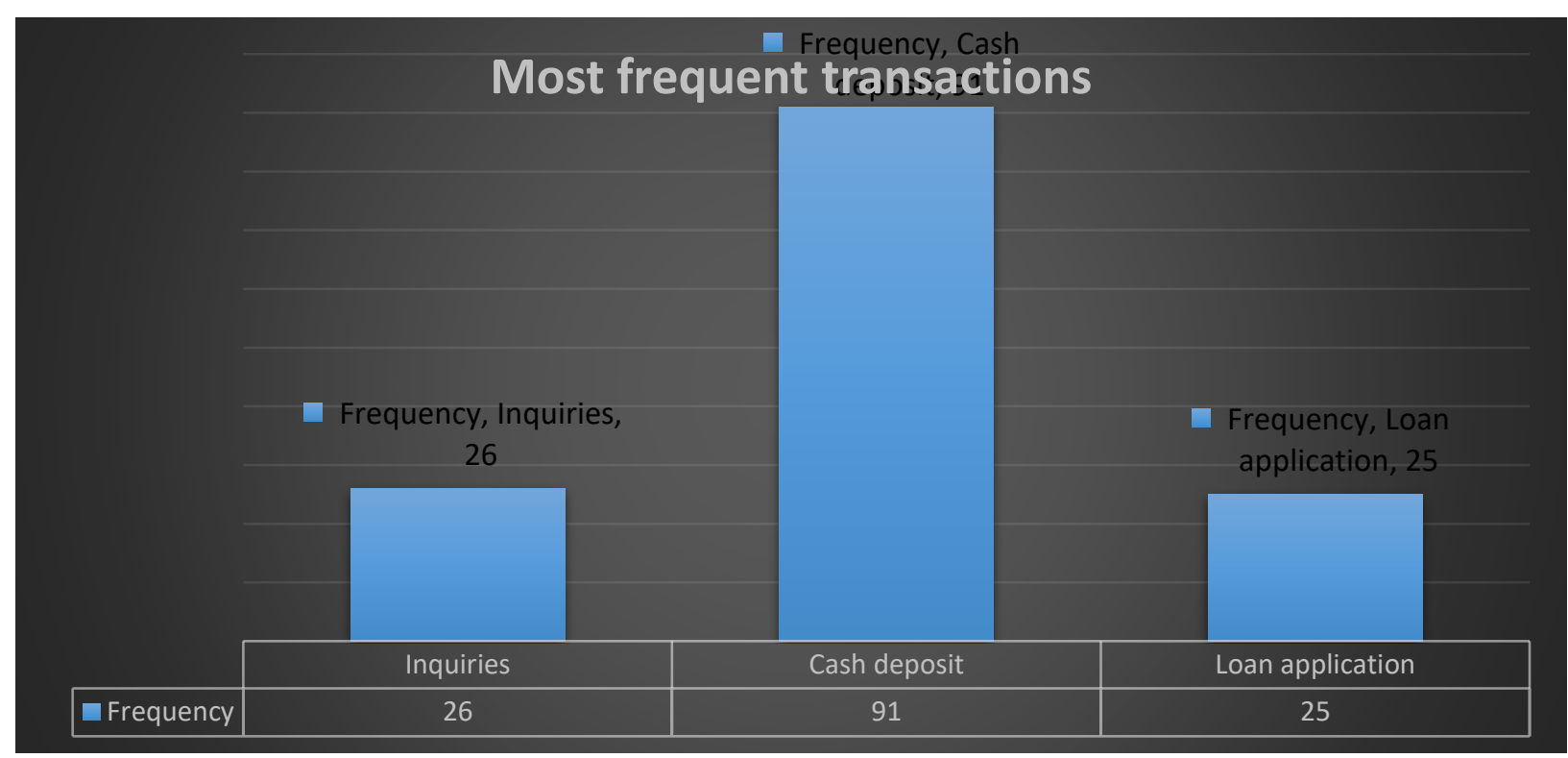

Figure 4: Most Frequent Transactions

Source: Field Data, 2017

Figure 4 above displays the transactions frequently are done by the respondents. It is observed that respondents have visited the MFIs mostly for enquiries, cash deposits and loan application. Out of these transactions, the cash deposit was recorded as the most frequent transactions done by the respondents with Loan application being the least.

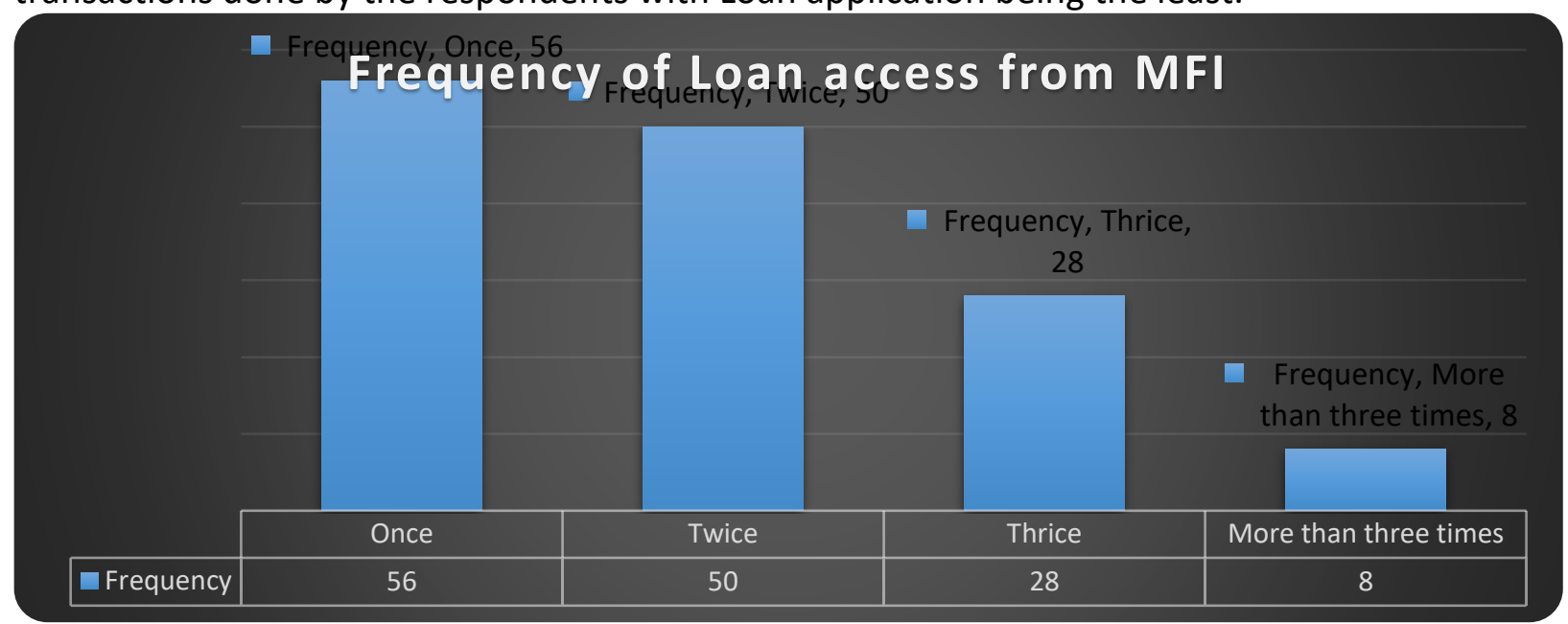

Figure 5: Frequency of Loans Accessed from MFIs

Source: Field Data, 2017

Figure 5 shows the frequency of loans accessed by respondents from the MFIs. It is observed that most of the respondents have accessed loans from the MFIs at least once; thus, $39.4 \%$ of the respondents have acquired a loan from the MFIs at least once. But it is also observed that very few had accessed loans more than three times. Thus only $5.6 \%$ had accessed loans more than three times from the MFIs. 


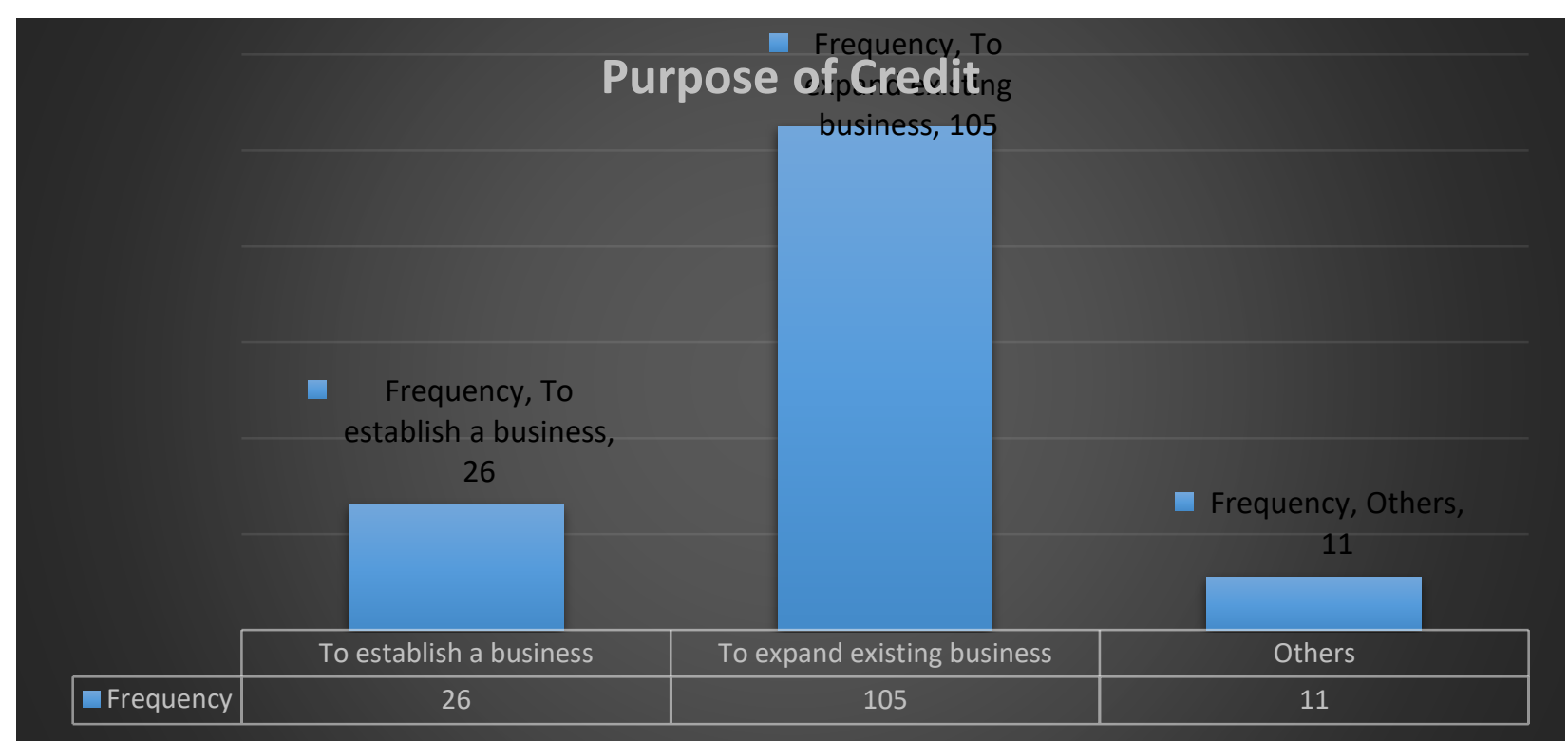

Figure 6: Purpose of Credit from MFIs

Source: Field Data, 2017

Figure 6 depicts the purpose of the loans accessed by the respondents. Most of the respondents used the loans to expand their existing business. Thus $73.9 \%$ of the respondents used the loans for expanding an existing business. Only $18.3 \%$ used the loans to establish a new business, and just $7.7 \%$ used it for other business.

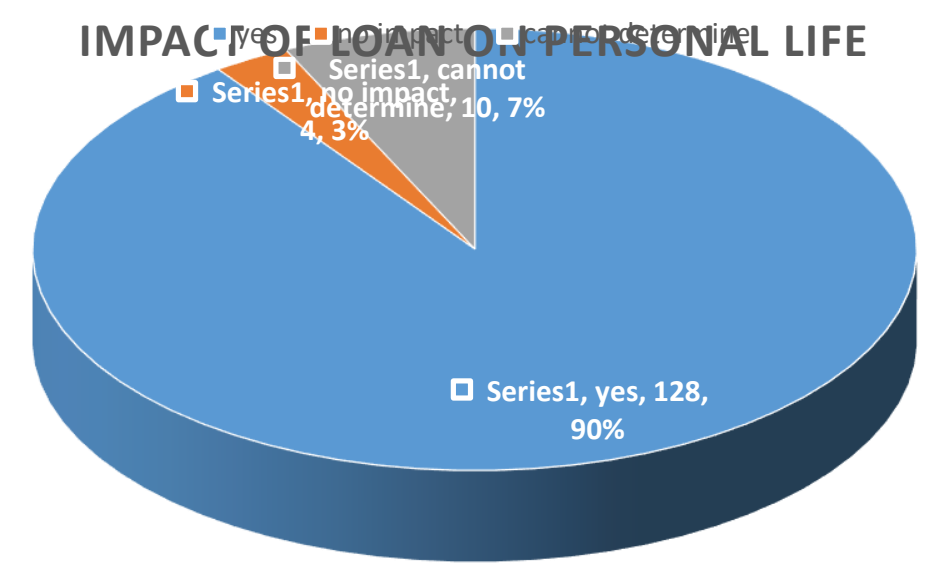

Figure 7: Impact of the credit acquired on personal Life Source: Field Data, 2017

The pie chart in figure 7 above presents the respondents perceive the impact of they obtain from MFIs on their personal lives. It is observed that $90 \%$ of the respondents feel that loans acquired have impacted positively on their lives. However, $3 \%$ of the respondents felt the loans had no impact on their personal lives, while $7 \%$ felt neutral about the impact of the loans. 
INTERNATIONAL JOURNAL OF ACADEMIC RESEARCH IN BUSINESS AND SOCIAL SCIENCES Vol. 10, No. 10, 2020, E-ISSN: 2222-6990 @ 2020 HRMARS

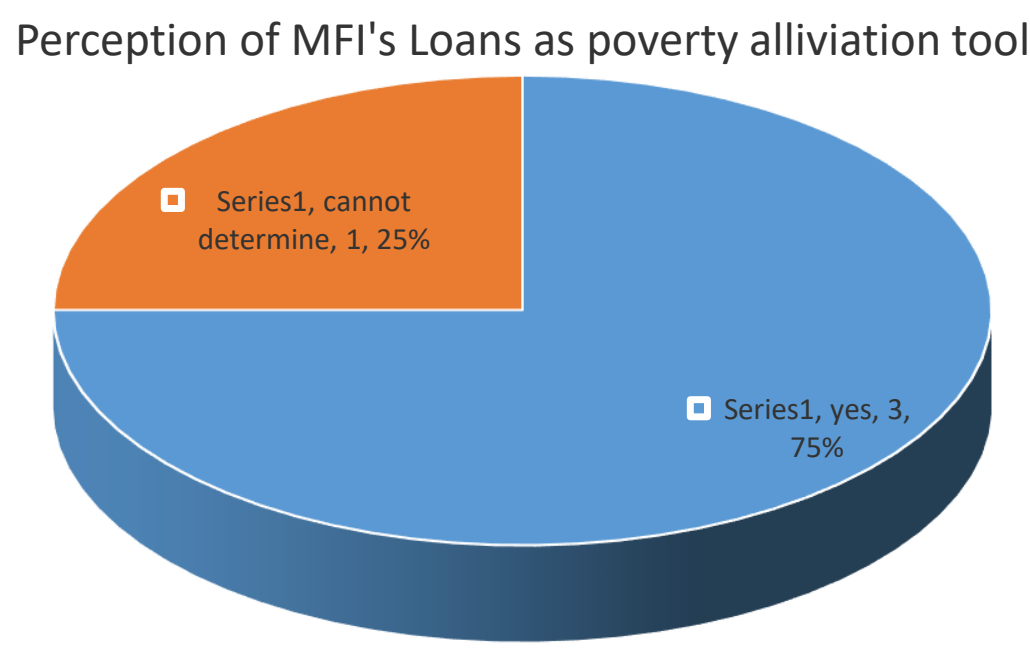

Figure 8: Perception of MFI's credits as Poverty alleviation tool

Source: Field Data, 2017

The pie chart in figure 8 also shows the perception of respondents on MFI's loans as a poverty alleviation tool. On this issue, $75 \%$ of the respondents responded affirmatively, while $25 \%$ felt they could not determine whether MFI loans are poverty alleviation tool.

\section{Assessment of services provided by MFIs}

The respondents assessed the quality of service provided by MFIs to them through the following indicators; assessment of customer service officers and tellers, assessment of frontline staffs, assessment of waiting periods for transactions, and assessment of overall services of the MFIs. 


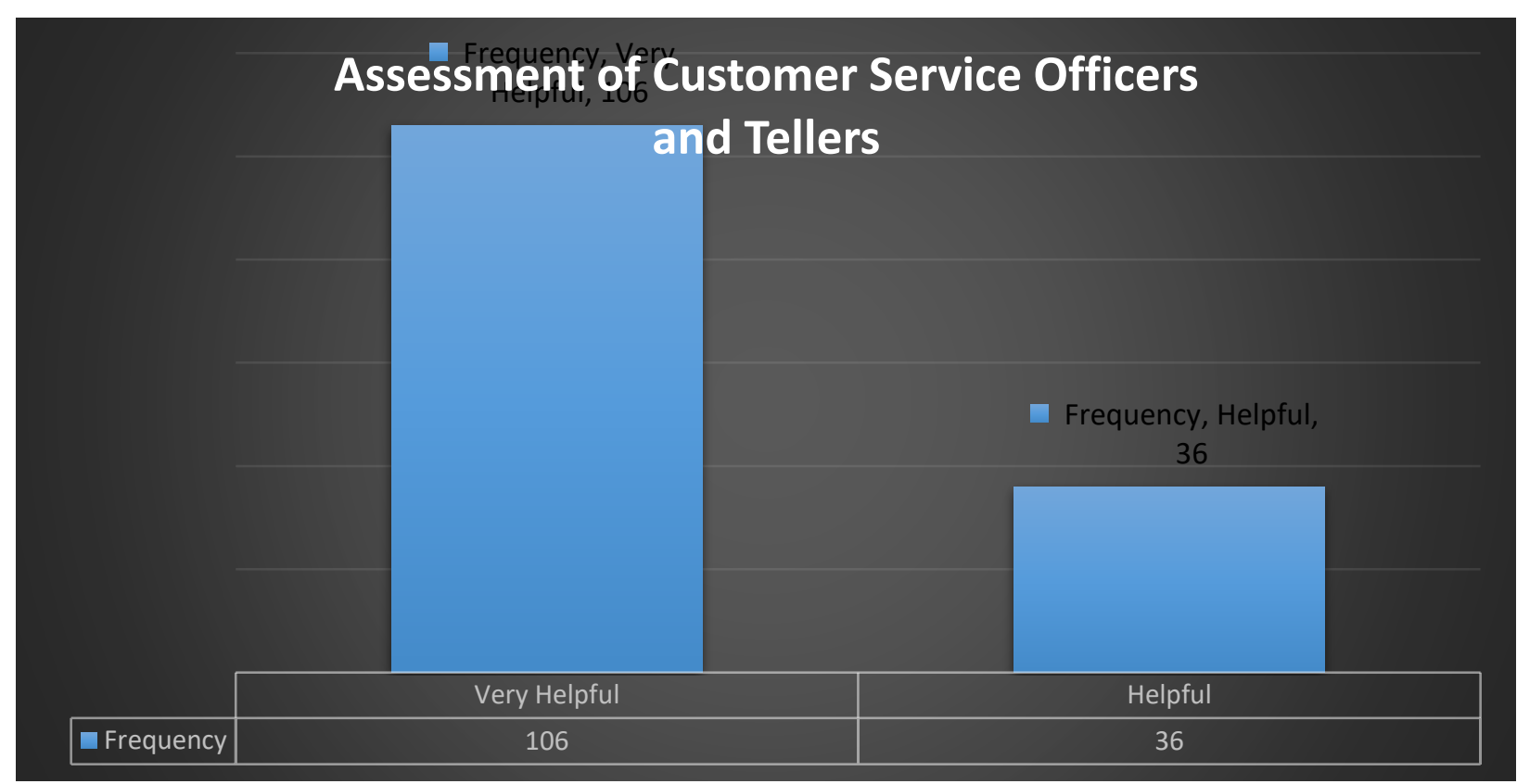

Figure 9: Assessment of Customer Service Officers and Tellers

Source: Field Data, 2017

Figure 9 above shows the assessment of customer service officers and tellers of the MFIs. The respondents overall thought they are very helpful. $74.6 \%$ thought they are very helpful whilst $25.4 \%$ rated them helpful.

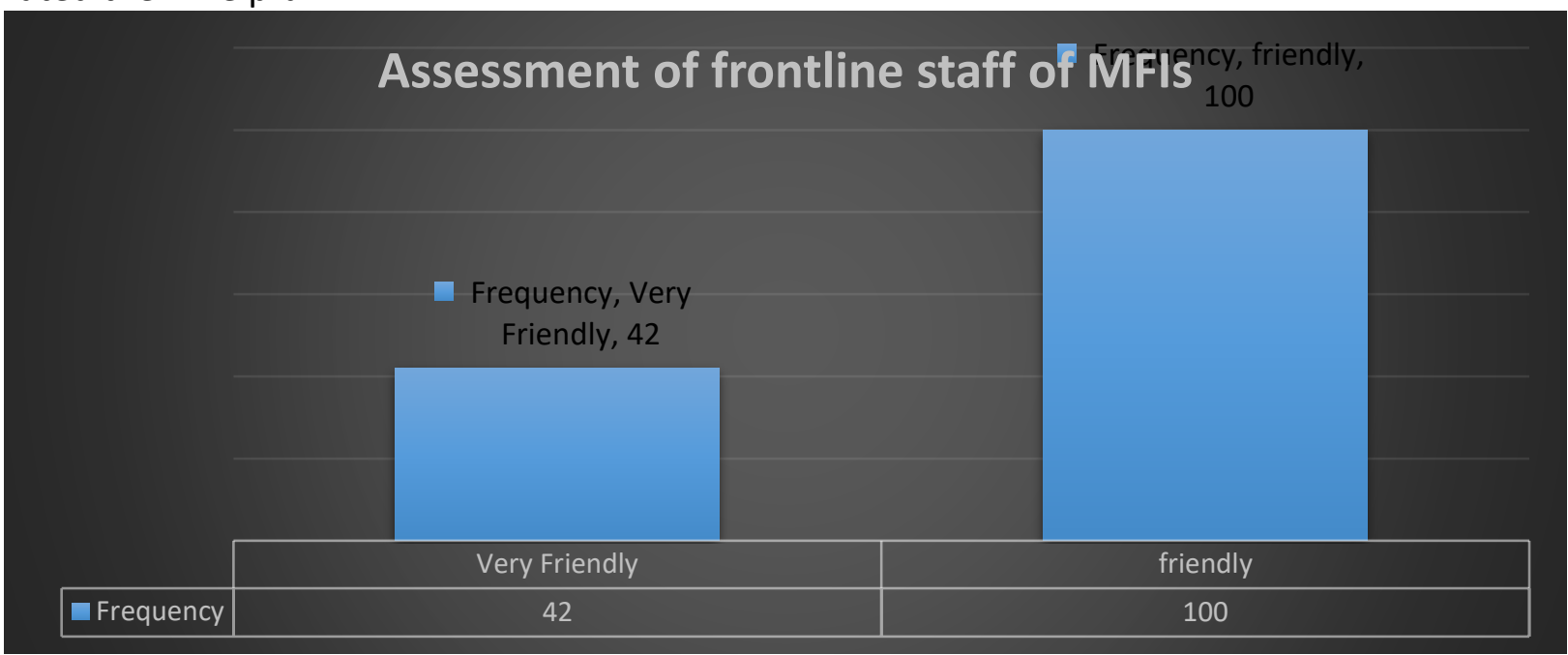

Figure 10: Assessment of Frontline Staff of MFIs

Source: Field Data, 2017

Assessing the friendliness of the frontline staff of the MFIs, figure 10 above displays the response of the respondents. $70.4 \%$ of the respondents rated them friendly, while the remaining $29.6 \%$ rated them very friendly. 


\section{Waitinguency, ${ }^{5}-10 \mathrm{c}$ for transactions}

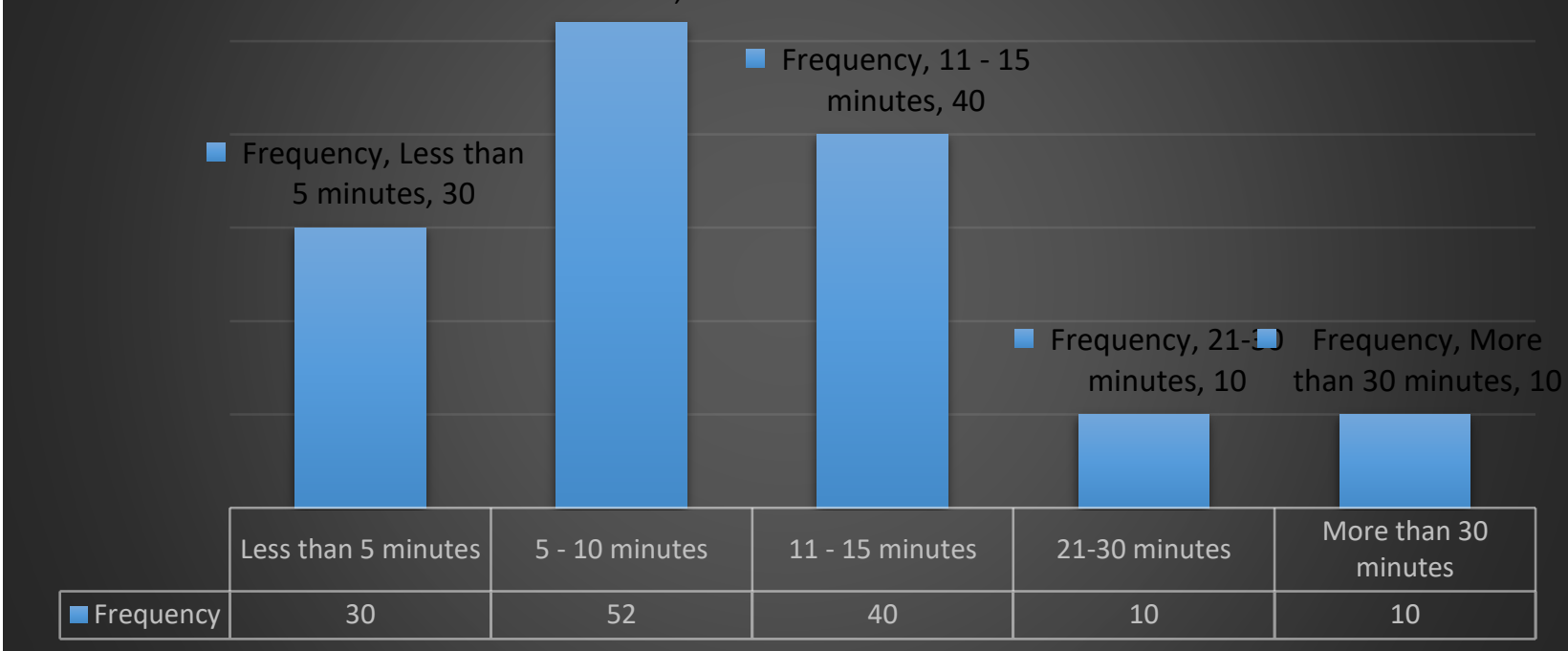

\section{Figure 11: Waiting Period for Transactions}

Source: Field Data, 2017

Figure 11 shows the waiting period respondents go through for transactions. It is observed that majority of them opined they spend 5-10 minutes for their transactions. However, some of them thus $28.2 \%$ and $21.1 \%$ opined that they waited for 11 to 15 minutes and less than five minutes, respectively. Few of them opined they waited for more than 21 minutes.

\section{Assegss,inent of overall services of MFls}

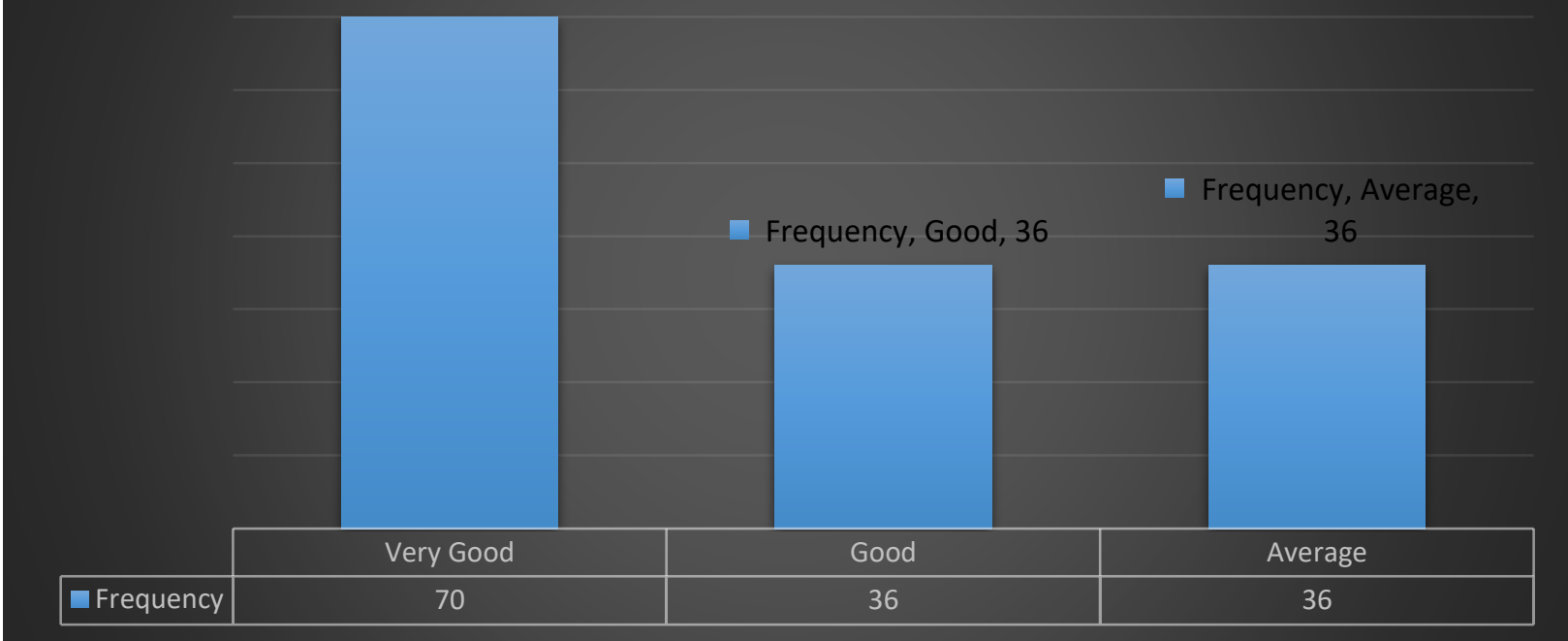

\section{Figure 12: Assessment of Overall Services of MFIs}

Source: Field Data, 2017

Figure 12 above displays the assessment of the overall services of MFIs. It is observed that 70 of them representing $49.3 \%$ rated their overall services as very good while on a split level of $25.4 \%$ each rated them as excellent and average. 
INTERNATIONAL JOURNAL OF ACADEMIC RESEARCH IN BUSINESS AND SOCIAL SCIENCES

Vol. 10, No. 10, 2020, E-ISSN: 2222-6990 @ 2020 HRMARS

\section{Challenges Associated with Attainment and Payment of Credit}

The challenges women face in accessing and paying of credits from MFIs were assessed via the following indicators; problems encountered while accessing credit and issues surrounding paying back of loans.

Table 3: Problems in Accessing Credit

\begin{tabular}{|l|l|l|l|l|l|}
\hline \multicolumn{2}{|l|}{ What problems did you encounter while accessing credit? } \\
\hline \multirow{2}{*}{} & Frequency & Per cent & Valid Percent & $\begin{array}{l}\text { Cumulative } \\
\text { Percent }\end{array}$ \\
\hline \multirow{3}{*}{ Valid } & issues of guarantors & 35 & 24.6 & 24.6 & 24.6 \\
\cline { 2 - 6 } & issues of collateral & 107 & 75.4 & 75.4 & 100.0 \\
\cline { 2 - 6 } & Total & 142 & 100.0 & 100.0 & \\
\hline
\end{tabular}

Source: Field data, 2017

Table 3 above shows the problems respondents encounter when accessing credit from MFIs. It is observed that two main issues came up-issues of guarantors and issues of collateral. $75.4 \%$ of the respondents stated collateral as their primary problem while accessing credit from the MFIs. The remaining $24.6 \%$ stated guarantors as their main problem.

Table 4: Loan Payments

Did you have any problems paying back?

\begin{tabular}{|l|l|l|l|l|l|}
\hline \multicolumn{2}{|c|}{} & Frequency & Per cent & Valid Percent & Cumulative Percent \\
\hline \multirow{4}{*}{ Valid } & Yes & 34 & 23.9 & 23.9 & 23.9 \\
\cline { 2 - 6 } & no & 108 & 76.1 & 76.1 & 100.0 \\
\cline { 2 - 6 } & Total & 142 & 100.0 & 100.0 & \\
\hline
\end{tabular}

If yes, what were the cause(s) for such difficulty?

\begin{tabular}{|l|l|l|l|l|l|}
\hline \multicolumn{2}{|c|}{} & Frequency & Per cent & Valid Percent & $\begin{array}{l}\text { Cumulative } \\
\text { Percent }\end{array}$ \\
\hline \multirow{3}{*}{ Valid } & Not Applicable & 108 & 76.1 & 76.1 & 76.1 \\
\cline { 2 - 6 } & unyielding business & 34 & 23.9 & 23.9 & 100.0 \\
\cline { 2 - 6 } & Total & 142 & 100.0 & 100.0 & \\
\hline
\end{tabular}

Source: Field Data, 2017

Table 4 above shows issues concerning loan payments. It is observed that when it comes to loan payments, $76.1 \%$ of the women opined they have no problems in paying back loans. Only $23.9 \%$ expressed difficulties in paying back loans. When quizzed further why they have difficulty paying back, all of them alluded to unyielding business as their primary challenge. When asked whether they receive any form of assistance from the MFIs in such difficulty, all of the $23.9 \%$ stated they received an extension in the repayment time (see table 5 below). 
INTERNATIONAL JOURNAL OF ACADEMIC RESEARCH IN BUSINESS AND SOCIAL SCIENCES Vol. 10, No. 10, 2020, E-ISSN: 2222-6990 @ 2020 HRMARS

Table 5: Assistance from MFls in terms of Difficulty in Payment

\begin{tabular}{|l|l|l|l|l|l|}
\hline \multicolumn{2}{|l|}{ What help (if any) did you receive from the institution when you were in such difficulty? } \\
\hline \multirow{4}{*}{ Valid } & Frequency & Per cent & Valid Percent & $\begin{array}{l}\text { Cumulative } \\
\text { Percent }\end{array}$ \\
\hline \multirow{3}{*}{$\begin{array}{l}\text { Extension in repayment } \\
\text { time }\end{array}$} & 34 & 23.9 & 23.9 & 23.9 \\
\cline { 2 - 6 } & Not Applicable & 108 & 76.1 & 76.1 & 100.0 \\
\cline { 2 - 6 } & Total & 142 & 100.0 & 100.0 & \\
\hline
\end{tabular}

Source: Field Data, 2017

Table 6: Decision on Accessing Further Loans

\begin{tabular}{|c|c|c|c|c|c|}
\hline \multicolumn{6}{|c|}{ Would you like to obtain another loan? } \\
\hline & & Frequency & Per cent & Valid Percent & Cumulative Percent \\
\hline \multirow{3}{*}{ Valid } & yes & 88 & 62.0 & 62.0 & 62.0 \\
\hline & no & 54 & 38.0 & 38.0 & 100.0 \\
\hline & Total & 142 & 100.0 & 100.0 & \\
\hline
\end{tabular}

\begin{tabular}{|l|l|l|l|l|l|}
\hline \multicolumn{2}{|l|}{ If no, Why? } & Frequency & Per cent & Valid Percent & $\begin{array}{l}\text { Cumulative } \\
\text { Percent }\end{array}$ \\
\hline \multirow{3}{*}{ Valid } & High Interest rate & 42 & 77.8 & 76.8 & 76.8 \\
\cline { 2 - 7 } & $\begin{array}{l}\text { capital accrued from loans } \\
\text { are enough to run business } \\
\text { now }\end{array}$ & 11 & 22.2 & 23.2 & 100.0 \\
\cline { 2 - 6 } & Total & 54 & 100.0 & 100.0 & \\
\hline
\end{tabular}

Source: Field Data, 2017

Table 6 above displays respondents' reaction when asked whether they would obtain another loan. The majority, thus $62 \%$ stated that they would access another loan, but a significant number, $38 \%$ of them maintained that they would not access another loan. The reasons being high-interest rate and that capital accrued from loans were enough to run their business. It is observed that $77.8 \%$ of the 54 respondents who state they will not go for another loan stated their reason to be that of the high interest rate. The remaining $22.2 \%$ opined they had accrued enough capital.

\section{Interviews}

The nature of the study demanded the contextual experience the managers to help ascertain what microfinancing in Ghana has done or is doing to promote women empowerment and the challenges they face in doing the same. Hence the use of interviews was appropriate to extract such experience from the management. The interview sessions started with introductory questions of a brief introduction about themselves and how long they have worked with the institution before delving into the substantive issues (interview guide in Appendix B).

Instead of a case by case analysis, a composite analysis is done and discussed under four thematic areas; what MFIs do to promote women empowerment; microfinance as a useful tool of 
INTERNATIONAL JOURNAL OF ACADEMIC RESEARCH IN BUSINESS AND SOCIAL SCIENCES Vol. 10, No. 10, 2020, E-ISSN: 2222-6990 @ 2020 HRMARS

women empowerment; major challenges of MFIs to promote women empowerment through microcredit; support MFIs have in place to facilitate loan repayment from women. These composite analysis and discussions are done in section 4.3 below.

\section{Discussion of Findings and Conclusion}

The discussion of the findings was done by reflecting on the data analysis in light of the research questions. The discussion was executed in a way to situate the understanding in a large context of the discourse of microfinance and women empowerment both in the Ghanaian context and the world.

The discourse was done around the following thematic areas: type of services provided by MFIs besides cash credit; the impact of microfinance on the living conditions of the beneficiary (women); Are the services provided by the MFIs satisfactory to the Ghanaian women; challenges Ghanaian women face in accessing loans from the microfinance institutions; major challenges of MFls to promote women empowerment through microcredit and microfinance as an effective tool of women empowerment.

\section{Characteristics of women clients of the MFIs}

It was observed from the data that women who have benefited from MFIs are of varied backgrounds (see Figures $1 \& 2$ ). The majority of the respondents were aged between 46 to 60, and most of them had an education to the JHS only $4.9 \%$ had no form of education. Most of them had about two to five dependents, and a majority were into trading.

\section{The impact of microfinance on the living conditions of the beneficiary (women)}

The impact of Microfinancing on the living conditions of women were assessed quantitatively through the following indicators; the number of years they have been with the MFIs, the most frequent transaction they do with the MFIs, the frequency of loans accessed from the MFIs, the Purpose for which they access to credit, their perception of the impact of credit accessed on their personal lives, and their perception on MFI loans as a poverty alleviation tool. It was observed that majority of the respondents had been with their MFIs for a period of two to five years with cash deposits being the most frequent transactions. It was observed that all the respondents have accessed loans from their respective MFIs at least once, but few have accessed it more than three times. The indication of fewer numbers accessing it more than three times is probably since when they were asked whether they intend accessing further loans, quite a number of them asserted that they might not access further loans mostly due to the high-interest rate. This goes to confirm the opinion of the critics of microfinance that microfinancing has deviated from its core calling of empowering the underprivileged through affordable microcredit (Peprah, \& Koomson, 2014). It is revealed the interest rate of the MFIs is scaring the women off from accessing the loans -the very people the MFIs are supposed to empower through financial support in terms of microcredit. Nevertheless, it was observed that cash deposits were their frequent transaction that gives an indication that the microfinance is helping the women to cultivate a habit of savings. Savings habits have been observed by researchers as one of the habits that help the poor out of poverty (Prina, 2015). This then is a positive sign that MFIs which extends their services to the doorsteps of the poor, provides the opportunity for the save against unforeseen contingencies. Again, it is observed that despite the challenges of high-interest rate, the majority of the women (75\%) are of the opinion that 
INTERNATIONAL JOURNAL OF ACADEMIC RESEARCH IN BUSINESS AND SOCIAL SCIENCES Vol. 10, No. 10, 2020, E-ISSN: 2222-6990 @ 2020 HRMARS

the loans help them out of poverty and a whopping $90 \%$ of them asserted that the loans have a positive impact on their personal life. This is in line with observations made by Dzisi and Obeng (2013) that MFI loans provide a way out of poverty to women.

\section{Assessment of services provided by MFIs}

The respondents assessed the quality of service provided by MFIs to them through the following indicators; assessment of customer service officers and tellers, assessment of frontline staffs, assessment of waiting periods for transactions, and assessment of overall services of the MFIs. They generally observed that the customer service officers and Tellers are very helpful and that the frontline staffs are very friendly. They waited for an average of 5 to 10 minutes for their transactions, and their overall assessment of the MFIs was very good.

These observations go to buttress researchers that MFIs are working hard to gain the trust of consumers and become a sure way to financial inclusion.

\section{Challenges Ghanaian women to face in accessing Loans from Microfinance Institutions}

The challenges women face in accessing and paying for credits from MFls were assessed via the following indicators; problems encountered while accessing credit and issues surrounding paying back of loans. The main challenges observed were the issues of guarantors and collateral for loans. This revelation brings to light that the MFIs are not practising the Grameen concept of micro crediting where loans were given without collateral, this observation is in contradiction to the view of Egyir and Akudugu (2009) that many MFIs in Ghana have modelled on the Grameen concept and has proven successful. Some $(23.9 \%)$ had problems of repayment of loans which was due unyielding businesses. This also indicates that the MFIs do not give enough 'after loans' advice on their businesses to help them have fruitful businesses. It was also observed that they had problems with interest rates charged on the loans to the extent that $38 \%$ of them were of the view they will not access further loans. Out of the $38 \%, 77.8 \%$ opined they would not access further loans due to highinterest rates charged.

\section{Major challenges of MFIs to promote women empowerment through microcredit}

It was noted from the interview that one of the major challenges that the MFIs are facing now is to win the goodwill of women to save and access loans from the MFIs due to the recent cases of frequent of MFIs in the country. The respondent from Brong-Ahafo region, most especially made a note of the collapse of DKM financial and God is Love financial service as a major reason women in the region are sceptical in keeping their money with MFIs. They asserted that there had been a drop in the women clients after such incidence hence reduction in women who access loans to inject in their business. They again observed that it is costly to give effective business advice to women after they access the loans; hence very little is done in terms of business advice. The cost of giving loans and loan defaults were also noted as major challenges that face the MFIs.

\section{Microfinance as an effective tool of women empowerment.}

Despite the challenges, they are of the view that Microfinance is an effective tool of women empowerment if the industry will be properly regulated to prevent the scammers (as they put it) out of the system. They observed that it is true that they (MFIs) have shifted attention a bit from empowering poor women through cheap loans to those who can afford the loans because the loans 
INTERNATIONAL JOURNAL OF ACADEMIC RESEARCH IN BUSINESS AND SOCIAL SCIENCES Vol. 10, No. 10, 2020, E-ISSN: 2222-6990 @ 2020 HRMARS

are expensive to give hence it warrants high-interest rate if they must stay in business. They recommended that the industry will need the presence of a strong supervisory and regulatory framework to streamline the industry and will need government subventions to support special units created to advance the course of women empowerment.

The study was prompted by the fact that empowering women to be economically viable through microfinancing projects has taken centre stage in development policy Nevertheless, there continue to be arguments for and against the role of microfinance in women empowerment. The study was, therefore, to evaluate the contributions of microfinance institutions in Ghana to the empowerment of the Ghanaian women, taking a specific interest in the challenges and prospects. Women empowerment were conceived in the study as ways of to increasing and improving the social, economic, political and legal strength of the women, to ensure equal right to women, and to make them confident enough to claim their basic rights. The study then looked at economic empowerment as the bedrock upon which all the others rest, therefore empowering women economically through the microfinancing became essential to achieve total women empowerment.

Perspectives were sought from women who are beneficiaries of microfinance and the management of MFIs. It was observed that microfinancing is playing a key role in contributing to individual lives of women by encouraging the providing the avenue for savings, providing loans and providing some level of business advice. This was in support of the views of the pro microfinance that microfinance institutions have amassed hundreds of case studies showing that the loans are given to beneficiaries' help alleviate poverty, improve health, increase education and promote women's empowerment. Nonetheless, the study also revealed that there is a bit of mission drift from the core object of the coming into being of MFIs to the extent that some MFIs target clients who can afford their loans at the interest rate charge backing it with the explanation of being able to sustain their business. The study revealed that this high-interest rate charged is pushing some women away from securing loans for their businesses. This also goes to support the view of the critics that Microfinance may not be the miracle that is sometimes claimed to be.

\section{Conclusion}

In conclusion the study revealed two main challenges facing the women to be: high-interest rate and the demand for guarantors and collateral for loans. The challenges facing the microfinance industry were: the decline of goodwill from the public, especially women client, lack of effective regulatory framework and high default rate, which makes the cost of loans very expensive.

Notwithstanding the challenges, the study observed that microfinance presents with greater prospects of empowering women economically through savings and loans only if the government will be up and doing to protect the industry from scammers with a strict supervisory and regulatory framework.

The study recommends that the government and non-governmental organisations should support private MFIs to set up special units for only women which will lax interest rate and provide extensive business support for them.

\section{References}

Addae-Koranky, A. (2012). Microfinance and Poverty Reduction in Ghana. The Case of Central Region of Ghana. Asian Economic and Financial Review, 2(1), 135.

Akotey, J. O., \& Adjasi, C. K. (2016). Does Microcredit Increase Household Welfare in the 
INTERNATIONAL JOURNAL OF ACADEMIC RESEARCH IN BUSINESS AND SOCIAL SCIENCES Vol. 10, No. 10, 2020, E-ISSN: 2222-6990 @ 2020 HRMARS

Absence of Microinsurance?. World Development, 77, 380-394.

Barreiro, P. L., \& Albandoz, J. P. (2001). Population and sample. Sampling techniques. Management Mathematics for European Schools MaMaEusch (994342-CP-12001-1-DECOMENIUS-C21.

Benard, C., Jones, S. G., Oliker, O., Thurston, C. Q., \& Lawson, B. S. (2008). Women and Nation-building. Rand Corporation.

Buvinic, M., \& Furst-Nichols, R. (2016). Promoting women's economic empowerment: what works?. The World Bank Research Observer, 31(1), 59-101.

Carter, S., \& Cannon, T. (1992). Women as entrepreneurs: A study of female business owners, their motivations, experiences and strategies for success. Cambridge: Academic Press.

CEDAW/C/39/D/5/2005. (2007). Council of Europe Treaty Series (CETS), No. 210, 5 Nov. 2014. Marital Rape: Consent, Marriage, and Social Change in Global Context, 205.

Committee on the Elimination of Discrimination Against Women (CEDAW). (2005). Elimination of All Forms of Discrimination Against Women: Ghana. Combined Third, Fourth and Fifth Periodic Reports of States Parties, CEDAW/C/GHA/4-5, CEDAW, New York: 59-71.

Creswell, J. W. (2013). Research design: Qualitative, quantitative, and mixed methods approaches. Thousand Oaks: SAGE.

Creswell, J. W. (2009). Editorial: Mapping the field of mixed methods research. Journal of Mixed Methods Research, 3(2), 95-108.

Dejene, Y. (2007). Promoting women's economic empowerment in Africa. In Africa Economic Conference, Addis Ababa (pp. 15-17).

D’Espallier, B., Guerin, I., \& Mersland, R. (2009). Women and repayment in microfinance (Working paper).

Duah, Y. F. E., Neequaye, E., \& Kissedu, E. A. (2012). Investment and Development Impact of Microfinance Institutions: A case study of Ghana. "Master's Thesis". Retrieved December, 2016, from http://urn.kb.se/resolve?urn=urn:nbn:se:bth-403

Dzisi, S., \& Obeng, F. (2013). Microfinance and the socio-economic wellbeing of women entrepreneurs in Ghana. International Journal of Business and Social Research, 3(11), 45-62.

Egyir, I. S., \& Akudugu, M. A. (2009). Rural Women and Microfinance in Ghana: Challenges and Prospects. Unpublished, 1-16.

Gill, J., \& Johnson, P. (2010). Research methods for managers. Thousand Oaks: SAGE.

Graziani-Garcia, M. R. (2011). Eliminating the Glass Ceiling: How Micro-Financing Empowers Women and Alleviates (Doctoral dissertation, University of Central Florida Orlando, Florida).

Hart, C. (1998). Doing a literature review: Releasing the social science research imagination. Sage.

Johnson, R. B., \& Onwuegbuzie, A. J. (2004). Mixed methods research: A research paradigm whose time has come. Educational researcher, 33(7), 14-26.

Kemper, E. A., Springfield, S., \& Teddlie, C. (2003). Mixed methods sampling strategies in social science research. In Tahakkori, A \& Teddlie, C, (Eds.). Handbook of mixed methods in social and behavioral research. Thousand Oaks, CA: Sage Publications, pp.273 - 296.

Khan, R. E. A., \& Noreen, S. (2012). Microfinance and women empowerment: A case study of District Bahawalpur (Pakistan). African Journal of Business Management, 6(12), 4514.

Krishna, A. (2003). Social Capital, Community Driven Development, and Empowerment: A short note on concepts and operations. World Bank working paper, 33077. 
INTERNATIONAL JOURNAL OF ACADEMIC RESEARCH IN BUSINESS AND SOCIAL SCIENCES Vol. 10, No. 10, 2020, E-ISSN: 2222-6990 @ 2020 HRMARS

Malhotra, A., \& Schuler, S. R. (2005). Women's empowerment as a variable in international development. Measuring empowerment: Cross-disciplinary perspectives, Washington, DC: World Bank, pp. 71-88.

Mouton, J. (1996). Understanding social research. Hatfield:Van Schaik Publishers.

Norwood, C. (2013). Macro Promises of Microcredit: A Case of a local eSusu in Rural Ghana. Journal of International Women's Studies, 7(1), 1-7.

Osei, A. J. (2007). Victor Microfinance in Ghana: An Overview. Research Department, Bank of Ghana.

Palmer, I., \& Dunford, R. (2008). Organizational change and the importance of embedded assumptions. British Journal of Management, 19(s1), S20-S32.

Peprah, J. A., \& Koomson, I. (2014). Addiction to Microcredit: An Obstacle to Social and Financial Mobility. Retrieved on January 3, 2017 from http://mpra.ub.uni-muenchen.de/57894/

Prina, S. (2015). Banking the poor via savings accounts: Evidence from a field experiment. Journal of Development Economics, 115, 16-31.

Rai, S. M. (2005). Equal Participation of Women and Men in Decision-making Processes, with Particular Emphasis on Political Participation and Leadership: Background Paper. UN. Department of economic and social affairs (DESA).

Rwomire, A. (2011). The role of social work in National Development. Social Work \& Society, 9(1), 108-118.

Saunders, M., Lewis, P., \& Thornhill, A. (2012). Research methods for business students. ed. so: Harlow: Pearson Education.

Schreiner, M. and Colombet, H.H. (2001). From Urban to Rural: Lessons for Microfinance from Argentina. Development Policy Review, Vol. 19, No.3, 339-354.

Sale, J. E., Lohfeld, L. H., \& Brazil, K. (2002). Revisiting the quantitative-qualitative debate: Implications for mixed-methods research. Quality and quantity, 36(1), 43-53.

Singh, Y. K., \& Bajpai, R. B. (2007). Research methodology: Techniques and trends. APH Pub

Sobhan, R. (2005). A macro policy for poverty eradication through structural change (No. 2005/03). WIDER Discussion Papers//World Institute for Development Economics (UNUWIDER).

Tegegne, M. E. S. S. A. Y. (2012). An assessment of the role of women in agriculture in Southern Nation Nationality People's Region: The case of Halabja Special Woreda, Ethiopia (Doctoral dissertation, Indira Gandhi National Open University).

Zoynul, A. M., \& Fahmida, M. (2013). Women Empowerment Through Microcredit: A Case Study of Dinajpur, Bangladesh. Studies in Business \& Economic, 8(2), 5-19. https://www.ghanabusinessnews.com/2014/12/18/masloc-disburses-gh\%C2\%A2153million-Since-beginning-CEO/, 6/23/2016 https://en.wikipedia.org/wiki/Microfinance. Date of retrieval 6/16/2016 